\title{
Havucun Verim ve Bazı Kalite Özellikleri Üzerine Sulama Suyu Tuzluluğu ve Kalsiyumun İnteraktif Etkileri
}

\author{
Ahmet Turhan' $\quad$ Neșe Özmen' Hayrettin Kușçu²* \\ 'Uludağ Üniversitesi Mustafakemalpașa Meslek Yüksekokulu 16500 Bursa \\ 2Uludağ Üniversitesi Ziraat Fakültesi Biyosistem Mühendisliği Bölümü 16059 Bursa
}

*Sorumlu yazar e-mail (Corresponding author e-mail): kuscu@uludag.edu.tr
Geliș tarihi (Received) : 01.12.2017
Kabul tarihi (Accepted): 12.12.2017
DOl : 10.21657/topraksu.410124

Öz

Tuz stresi, tarımsal üretimde önemli abiyotik stres etmenlerinden biridir. Bu çalıșmanın amacı, havuç (Daucus carota L.) bitkilerinde sulama suyu tuzluluğu ve tuzluluk stresinin zararlı etkilerinin azaltıması üzerine $\mathrm{Ca}^{2+}$ uygulamalarının etkilerini araștırmaktır. Çalıșma, Uludağ Üniversitesi Mustafakemalpașa Meslek Yüksekokulunda yer alan bir serada yürütülmüștür. Sulama suyundaki beș farklı NaCl düzeyine (0, 20, 40, 60 ve $80 \mathrm{mM}$ ) ek olarak, denemeler her bir NaCl düzeyi için toprağa uygulanan 0, 4 ve 8 mM Ca ${ }^{2+}$ ile tekrarlanmıștır. Araștırma, bölünmüș parseller deneme desenine uygun olarak 4 tekerrürlü yürütülmüș, her tekerrürde 1 adet lizimetre ve her lizimetrede de 12 adet havuç bitkisi olacak biçimde planlanmıștır. Araștırma sonuçlarına göre, sulama suyu tuzluluğu arttıkça pazarlanabilir verim azalmıștır. Kalite parametrelerinde (meyve su içeriği, suda çözünür kuru madde, indirgen șeker, $\beta$-karoten ve vitamin C) ise tuzun olumsuz etkileri 20 mM üzerinde artan tuz konsantrasyonlarında görülmüștür. Tuzlu ortamda Ca ${ }^{2+}$ uygulamaları, havucun suda çözünür kuru madde, indirgen șeker, $\beta$-karoten ve vitamin C içeriklerinde tuzun olumsuz etkilerini hafifletmiștir. Diğer taraftan, pazarlanabilir havuç verimi, meyve su içeriği ve toplam asit değerleri üzerinde kalsiyum uygulamalarının herhangi bir pozitif etkisinin olmadığı belirlenmiștir. Bu bulgular, sulama suyundaki tuz konsantrasyonuna ek olarak toprağa uygulanan ilave $\mathrm{Ca}^{2+}$ uygulamasının doğru bir șekilde yönetilmesinin, havucun bazı kalite parametrelerini iyileștirmek için etkili bir araç olabileceğini göstermektedir.

Anahtar kelimeler: havuç, tuzlu su, kalsiyum, kalite

\section{Interactive Effects of $\mathrm{Ca}^{2+}$ and Irrigation Water Salinity on Yield and Some Quality Parameters of Carrot}

\begin{abstract}
Salt stress is one of the major abiotic stress factors in agricultural production. The aim of the present study is to investigate the effects of irrigation water salinity and the influence of supplemental $\mathrm{Ca}^{2+}$ on the alleviation of the deleterious effects of salinity stress in carrots (Daucus carota L.). The study was carried out in a greenhouse located at Uludag University Mustafakemalpașa Vocational School. In addition to four $\mathrm{NaCl}$ levels of $0,20,40,60$ and $80 \mathrm{mM}$ in irrigation water, the treatments were repeated with 0, 4 and $8 \mathrm{mM} \mathrm{Ca}{ }^{2+}$ applied to the soil at each $\mathrm{NaCl}$ level. Research was laid out in randomized parcel design with five replications and 12 plants in each replication on lysemeters formed in greenhouse. According to the results, increasing irrigation water salinity decreased
\end{abstract}


the marketable yield. In the quality parameters (fruit juice content, soluble solids, reducing sugar, $\beta$-carotene and vitamin C), adverse effects of salt stress were observed at increasing salt concentrations above $20 \mathrm{mM}$. $\mathrm{Ca}^{2+}$ applications in the saline soil alleviated the negative effects of salt on soluble solids, reducing sugar, $\beta$-carotene and vitamin $C$ contents of carrots. On the other hand, it has been determined that there is no positive effect of calcium applications on marketable yield, fruit juice content and total acid values. These findings suggest that a proper management of the salt concentration of the irrigation water plus additional Ca ${ }^{2+}$ applications to soil may provide an efficient tool to improve the some quality parameters of carrots.

Key word: Carrot, water salinity, calcium, quality

\section{Gíriș}

Tuz stresi, tarımsal üretimde önemli abiyotik streslerden biridir. Dünyadaki arazilerin \%20 'lik kısmı tuzluluk problemi etkisi altındadır (Zhu, 2001). Türkiye'de yaklașı 1.5 milyon hektarda tuzluluk ve alkalilik sorunu bulunmaktadır. Bu, sulamaya uygun arazilerin yaklașık \%32.5'ine denktir (Ekmekçi, 2005). Tuzluluk, yağıșın az buharlașmanın fazla olduğu kurak ve yarı kurak iklim bölgelerinde etkili olmaktadır. Bu bölgelerde yıkanarak yeraltı suyuna karıșan çözünebilir tuzlar yüksek taban suyuyla birlikte kapilarite yoluyla toprak yüzeyine çıkmakta ve buharlașma sonucu tuzun toprak yüzeyinde ve yüzeye yakın bölümünde birikmesine neden olmaktadır (Kwiatowsky, 1998; Kara, 2002). Diğer taraftan, toprakta tuz birikimi kalitesiz sulama suları ve așırı gübre kullanımından da kaynaklanabilmektedir (Zhu, 2001).

Tuz stresinin en büyük etkisi birçok kültür bitkisinde büyüme ve gelișmenin azalmasıdır. Bitki gelișiminde tuzluluğun zararlı etkileri, toprak çözeltisinin ozmotik potansiyeli, beslenme dengesizliği, özel iyon etkisi ve bu faktörlerin kombinasyonu ile ilișkilidir. Ozmotik stres, sodyum iyonlarının direkt bir etkisi olmaksızın su eksikliğinden kaynaklanmaktadır (Munns, 2002). Beslenme dengesizliği ise așırı miktarda $\mathrm{Na}$ ve $\mathrm{Cl}$ birikiminden kaynaklanmakta ve K, $\mathrm{Ca}, \mathrm{Mn}, \mathrm{NO}_{3}$ gibi besin elementlerinin alımının azalmasına neden olmaktadır (Hasegawa vd., 2000; Viegas vd., 2001). Tuzun yüksek olduğu toprak koșullarında yetiștirilen bitkilerde, köklerle yüksek oranda Na iyonu alınmakta ve bu iyonun bitki organlarına tașınmasıyla bitki bünyesindeki miktarı yükselmektedir. K ve Ca alımlarındaki ve tașınımlarındaki azalma ile bitki organlarındaki oranları düșmektedir. Ca ve $\mathrm{K}$ iyonları fizyolojik olaylarda anahtar rol oynarken, Na iyonunun besin elementi olarak etkisi yoktur. Ayrıca Na iyonunun K ve Ca iyonlarına karșı artıș göstermesi iyon dengesizliğine neden olmaktadır (Al-Karaki, 2000).

Havuç tuzluluğa duyarlı bir sebze olarak sınıflandırımaktadır (Gibberd vd., 2002). Havuç veriminde azalma, toprak saturasyon eriyiği elektriksel iletkenliğinin 1 dS $\mathrm{m}^{-1}$ 'nin üzerine çıkmasıyla bașlamaktadır (Rhoades vd., 1992).

Tuzlu topraklarda tarımsal üretimin devamlıı̆ı, yetiștiriciliği sınırlayan tuzluluk düzeyinin düșük tutulmasıyla olasıdır (Akat ve Özzambak, 2013). Tuzun zararlı etkilerini azaltmak için yapılan çalıșmalar daha çok ek K ve Ca uygulamalarına odaklanmıștır (Reid ve Smith, 2000). Navarro vd. (2000) yaptıkları çalıșmada tuza dayanımın arttırımasında kalsiyumun önemli rolünün olduğunu belirtmișlerdir. Tuzluluktaki artıș ile birlikte kalsiyum alımı da azalmaktadır. Tuz stresine maruz kalmıș bitkilere ilave kalsiyum uygulaması, bitkilerin strese karșı koyabilme kapasitesini arttırmaktadır (Martinez-Ballesta vd., 2000). Diğer taraftan, kalsiyum uygulamaları ile köklerin azot, potasyum ve fosfor alımlarının da arttığı, hücre duvarının, dolayısı ile dokuların güçlendiği, fotosentezin hızlandığı, domates ve șeker pancarı gibi bazı bitkilerde meyve kalitesinde iyileșme ve meyve büyüklüklerinde artıș meydana geldiği rapor edilmiștir (Fenn vd., 1991). Tuza maruz kalmıș bitkilerde kalsiyum uygulamasının, sodyum alımını azalttığı, buna karșın potasyum ve kalsiyum alımını arttırdığı, bitkilerde büyümeyi teșvik ettiği için önemlidir. Tuzlu koșullarda yetiștirilen çileklere uygulanan $\mathrm{CaSO}_{4}$ meyve verimi ve kalitesinde önemli miktarda artıșa neden olmuștur (Khayyat vd., 2007).

Tuz miktarı düșük kaliteli sulama sularının bulunamadığı durumlarda, havuç gibi sebzeler çoğunlukla değișik miktarda tuz içeren düșük 
kaliteli yer altı suları ile sulanmaktadır. Düșük kaliteli sulama sularının kullanılması, verim ve kaliteyi olumsuz etkilemektedir. Olumsuz koșulların bitki gelișimini sınırlandırıcı etkisini azaltmak ve verimliliğini artırmak amacıyla bazı önlemler alınabilmektedir. Bu bağlamda, birçok araștırıcı tuz ve kalsiyum arasındaki ilișkilere odaklanmıștır (Reneault vd., 2001). Renault ve Affifi (2009)'de bildirdiği gibi tuzun zararlı etkilerini azaltmak için yapılan kalsiyum uygulamalarından olumlu sonuçlar alınabilmiștir. Caines ve Shennan (1999) domates genotiplerinde yaptığı çalıșmada, tuz uygulamasının gövde büyümesini olumsuz etkilediğini ve bu olumsuz etkilerin ilave Ca 10 mM, $\mathrm{CaSO}_{4}$ ) uygulaması ile azaltılabileceğini bildirmiștir. Fasulye bitkilerinde yapılan diğer çalıșmada ise ilave $\mathrm{Ca}\left(\mathrm{CaSO}_{4}\right)$ uygulamalarının tuz stresi etkilerini azalttığı ve uygulama dozlarının da 1-10 mM arasında olması gerektiğini vurgulamıștır (Lahaye ve Epstein, 1971). Tuz zararının azaltılmasında düșük konsantrasyonlu Ca uygulamaları, yüksek konsantrasyonlu uygulamalara göre daha etkilidir (Grattan ve Grieve, 1999).

Bu çalıșmada havuçlarda kullanılacak sulama sularının tuzluluk sınırının belirlenmesi, farklı tuz konsantrasyonlarının pazarlanabilir verim ve kalite parametrelerine etkisinin araștırıması amaçlanmıștır. Bununla birlikte, havuç bitkilerinde tuz ve kalsiyum uygulamaları arasındaki ilișkilerin incelendiği araștırma sayısı çok sınırlıdır. Bu bağlamda, çalıșmamızın diğer bir amacı da tuz zararının azaltılması için alınabilecek önlemlerden birisi olan kalsiyum uygulamalarının etkisini havuç bitkilerinde araștırmaktır.

\section{Materyal ve Yöntem}

Çalıșma, Uludağ Üniversitesi Mustafakemalpașa Meslek Yüksekokulu deneme arazisinde kurulu, plastik örtülü uygulama serasında $\left(40^{\circ} 02^{\prime} \mathrm{N}\right.$, 28 23' E; deniz seviyesinden yükseklik $22 \mathrm{~m}$ ) yürütülmüștür. Yetiștirme süresi boyunca sera ortamındaki ortalama sıcaklık ve nem, sırasıyla $22^{\circ} \mathrm{C}$ ve \%69 olarak ölçülmüștür. Araștırmada bitkisel materyal olarak, ülkemiz havuç yetiștiriciliğinde önemli bir yeri olan ve ticari olarak üretimi yapılan 'Nantes' (Daucus carota L.) havuç çeșidi kullanılmıștır.

Araștırma, bölünmüș parseller deneme desenine uygun olarak 4 tekerrürlü yürütülmüș, her tekerrürde 1 adet lizimetre ve her lizimetrede de 12 adet havuç bitkisi olacak biçimde planlanmıștır. Silindirik yapııı 10.85 m yüksekliğinde ve $0.58 \mathrm{~m}$ çapındaki) lizimetrelerin içerisine, 200 kg hava kurusu kumlu-killi-tın bünyeye sahip toprak (\%60 kum, \%21 kil, \%19 silt, \%1.3 organik madde, kireç \%10.26, fosfor 35.6 ppm, potasyum 355.20 ppm, toplam azot \%0.09, $\mathrm{pH}=7.4, \mathrm{EC}=0.26 \mathrm{dS} \mathrm{m}^{-1}$, hacim ağırlığı $1.23 \mathrm{~g} \mathrm{~cm}^{-3}$, tarla kapasitesi \%25, devamlı solma noktası \%12) 2 mm göz açıklıklı elekten elendikten sonra doldurulmustur. Lizimetrelerin tabanına, drenaj suyunun toplanması için bir musluk monte edilmiș, olası drenaj suyunun kolaylıkla tahliye edilebilmesi için $5 \mathrm{~cm}$ kum-çakıl karıșımı yerleștirilmiștir. Lizimetrelere temel gübre olarak, $90 \mathrm{~kg} \mathrm{ha-1} \mathrm{N}$ (Üre) ve $90 \mathrm{~kg} \mathrm{ha}^{-1} \mathrm{P}_{2} \mathrm{O}_{5}$ (Diamonyum fosfat), $5 \mathrm{~kg}$ ha' $^{-1} \mathrm{~K}_{2} \mathrm{O}$ (potasyum sülfat) uygulanmıștır. P ve K gübrelerinin tamamı ve $N$ gübresinin yarısı ekimden önce, $N$ gübrenin diğer yarısı da ilk tuz uygulamasından 20 gün sonra verilmiștir (Ünlükara vd., 2011). Havuç tohumları; lizimetreye sıra üzeri $12 \mathrm{~cm}$ ve sıra arası $25 \mathrm{~cm}$ mesafelerde, 25 Temmuz'da ekilmiștir. Ekimden hemen sonra saf su uygulanmıș ve bitkilere gerekli bakım ișlemleri deneme süresince düzenli olarak yapılmıștır.

Tohum ekimi ile birlikte 15 Ağustos'a kadar sulamalarda saf su kullanılmıș ve daha sonraki uygulamalarda ise konulara göre sulama uygulanmıștır. Uygulama konusu olarak 2 faktör ele alınmıștır. Ana faktör olarak 5 tuz (NaCl) dozu ( $\mathrm{T}_{0}: 0 \mathrm{mM}, \mathrm{T}_{20}: 20 \mathrm{mM}, \mathrm{T}_{40}: 40 \mathrm{mM}, \mathrm{T}_{60}$ : $60 \mathrm{mM}$ ve $T_{80}: 80 \mathrm{mM}$ ) alt faktör olarak ise 3 kalsiyum (Ca) düzeyi (Ca: $0 \mathrm{mM}, \mathrm{Ca}_{4}: 4 \mathrm{mM}$ ve $\mathrm{Ca}_{8}: 8 \mathrm{mM}$ ) uygulanmıștır. Tuzlu sulama sularının hazırlanmasında suda eriyebilme kapasitesi yüksek olan $\mathrm{NaCl}$ tuzu ve ilave kalsiyum uygulamalarında da $\mathrm{CaSO}_{4}$ (kalsiyum sülfat) kullanılmıștır. Çözeltilerin hazırlanmasında kullanılan çeșme suyunun EC değeri $0.32 \mathrm{dS} \mathrm{m}^{-1}$, Ca ve Na değerleri ise sırasıyla

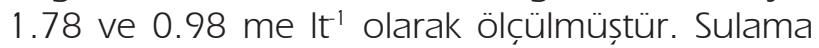
programının uygulanması için A sınıfı buharlașma kabından olan buharlașma miktarları esas alınmıș ve kap katsayısı 1 olarak kabul edilmiștir. Sulama aralığı, Bursa ilinde çiftçilerin havuç yetiștiriciliğinde yaygın olarak tercih ettiği 3 gün olarak alınmıș ve her deneme konusuna aynı zamanda sulama uygulaması yapıImıștır. Sulamalar, vejetasyon süresi boyunca, ölçülü bir kap aracılığı ile düșük hızda bitki kök bölgesine verilmiș ve toplamda 30 kez sulama yapılmıștır. Deneme boyunca 15 gün aralıklar ile tüm lizimetrelerin her 15 cm'lik katmanından, Hollanda tipi toprak burgusu 
ile toprak örnekleri alınarak kurutulmuș ve bu örnekler üzerinde, elektriksel iletkenlik değerleri 1:2.5 oranında saf su ile sulandırılmıș toprak örneklerinde EC metre (TD Scan-4 model, Eutech Inst. Singapur) ile ölçülmüștür.

Deneme sonunda her lizimetredeki tüm havuçlar el ile yapraklı olarak sökülmüș, bitkinin yan kökleri ve yaprakları kesilmiș, havuç üzerindeki topraklar yıkanarak arındırılmıștır. Pazarlanabilir verim $\left(\mathrm{kg} \mathrm{da}^{-1}\right)$, düzgün șekilli, sağlam, yarıksız, çatlaksız, sıyrıksız, çatallanmamıș, yan kök yapmamıș, hastalık ve böcek zararları olmayan, çeșit özelliklerini gösteren, 2.0-3.5 cm çaplı, havuçlar tartılarak bulunmuștur.

Hasat edilen havuçların yenilebilir kısımlarından kalite parametrelerinin belirlenmesi için örnek alınmıștır. Buna göre her uygulamanın her tekerrüründe rastlantısal olarak 6 adet havuc, olacak șekilde örneklemeler yapılmıș, örnekler bolca çeșme suyu ve sonra saf sudan geçirilerek temizlenmiș, öğütülmüștür. Oransal su içeriğinin (w) bulunabilmesi için, elde edilen meyve püresinden alınan örnekler $70^{\circ} \mathrm{C}$ sabit sıcaklıkta 48 saat etüvde kurutularak meyve kuru ağırlıkları (\%) tespit edilmiș ve Noshadi vd. (2013)'e göre, oransal su içeriği $W=\left[\left(W_{1}-W_{2}\right) / W_{1}\right] \times 100$ (W1= taze ağırlık g, w2= kuru ağırık g) formülünden hesaplanmıștır.

Meyve suyunda suda çözünebilir kuru madde içeriği (\%), refraktometre (Abbe-type refractometer, model 60/DR) ile ölçülmüștür (Tigchelaar, 1986). Toplam asitlik (\%) ise aynı meyve suyunun $0.1 \mathrm{~N}$ $\mathrm{NaOH}$ ile titrasyonu sonucu belirlenmiștir. Șeker analizleri için Luff-Schoorl yöntemi kullanılmıș ve havuç örneklerindeki indirgen șeker miktarı \% olarak hesaplanmıștır (Gormley ve Maher, 1990). ß-karoten içeriği Cemeroğlu (2010)'nun belirttiği yöntem ile saptanmıștır. Bu yöntemde; karotenoidler, analiz edilecekmateryalden metanol ve petrol eter ile ekstrakte edilmiș, ekstraktaki karotenoidler fotometrik (Shimadzu UV-1208, Shimadzu Co., Kyoto, Japan) olarak 350-750 nm'de belirlenmiș, maksimum absorbans değeri ile ekstriksiyon katsayısı 2500 alınarak $\beta$-karoten mg $100 \mathrm{~g}^{-1}$ olarak hesaplanmıștır. Örneklerde vitamin C (askorbik asit) içeriği ise Pierson (1970) tarafından tanımlanan spektrofotometrik diklorofenolindofenol yöntemi ile saptanmıș ve mg $100 \mathrm{~g}^{-1}$ olarak ifade edilmiștir.

Sulama suyu tuzluluğu ile pazarlanabilir havuç verimi ve toprak tuzluluğu arasındaki ilișkileri belirlemek amacıyla MS Excel hesap tabloları kullanılarak regresyon analizleri yapılmıștır. Havuçlardan elde edilen verim ve kalite parametrelerine ilișkin sayısal veriler varyans analizi ile değerlendirmeye tabi tutulmuș ve ortalamalar arasındaki farklılıklar LSD testi ile saptanmıștır. İstatistikî analizlerde bir paket program (IBM®) SPSSR Statistics for Windows, Version 20.0, Copyright, 2011, IBM Corp., Armonk, NY) kullanılmıștır.

\section{Bulgular ve Tartıșma}

Bu çalıșmada, sulama suyu tuzluluk düzeyi arttıkça pazarlanabilir havuç verimi azalmıștır. Benzer çalıșmalarda, tuz stresinin havuç bitkilerinin verim değerlerini önemli miktarda azalttığı belirtilmiștir (Bakhsh vd., 2005; Fabre vd., 2011 ; Ünlükara vd., 2011 ; Kahouli vd., 2014). Sulama suyundaki farklı tuzluluk düzeyleri ile pazarlanabilir verim arasındaki ilișkinin belirlenmesi için regresyon analizi yapılmıștır. Regresyon analizi sonunda, sulama suyu tuzluluğu ve pazarlanabilir verim arasında $Y=3650-30.94[E C W]\left(R^{2}=0.93\right)$ ile tanımlanan doğrusal bir ilișki bulunmuștur (Șekil 1).

Ayrıca, sulama suyu tuzluluğu ile hasat sonu toprak tuzluluğu değerleri arasında $\mathrm{EC}_{1 / 2.5}=$ $0.0006[\mathrm{ECW}]^{2}+0.0089[\mathrm{ECW}]+0.6704\left(\mathrm{R}^{2}=\right.$ $0.97)$ biçiminde 2 . dereceden polinomiyel bir eșitlik elde edilmiștir (Șekil 2). Bu eșitliğe göre, artan sulama suyu tuzluluğu ile toprakta biriken tuzluluk düzeyinin tedrici olarak artıș gösterdiği, sulama suyu tuz konsantrasyonun yüksek

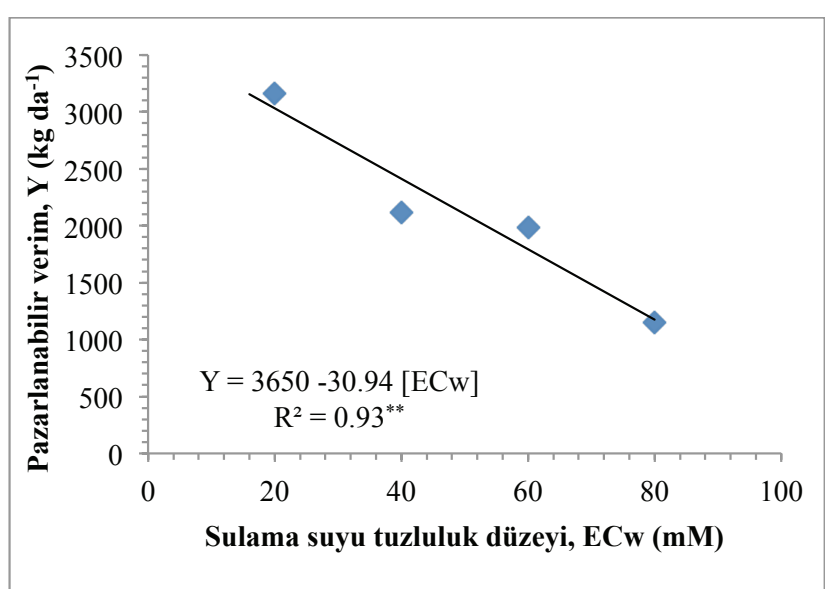

Şekil 1. Havuç bitkisinde sulama suyu tuzluluğu ve pazarlanabilir verim ilișkisi

Figure 1. Relationship between irrigation water salinity and marketable yield of carrot plant 
değerlerinde toprakta daha fazla tuz birikimi oluștuğu söylenebilir. Deneme konularının tümüne yetiștiricilik mevsimi genelinde eșit miktarda sulama yapılmıș ve A sınıfı buharlașma kabına dayalı olarak toplamda 97.1 It lizimetre ${ }^{-1}$ su verilmiștir. Ancak tuzluluğun daha yüksek olduğu konularda, tuzluluğun etkisiyle azalan bitki su tüketimi sonucu daha fazla oranda drenaj suyu çıkmıștır. Buna göre, $\mathrm{T}_{0}+\mathrm{Ca}_{0^{\prime}} \mathrm{T}_{0}+\mathrm{Ca}_{4^{\prime}} \mathrm{T}_{0}+\mathrm{Ca}_{8^{\prime}}$ $\mathrm{T}_{20}+\mathrm{Ca}_{0^{\prime}} \mathrm{T}_{20}+\mathrm{Ca}_{4}, \mathrm{~T}_{20}+\mathrm{Ca}_{8^{\prime}} \mathrm{T}_{40}+\mathrm{Ca}_{0^{\prime}} \mathrm{T}_{40}+\mathrm{Ca}_{4^{\prime}} \mathrm{T}_{40}$ $+\mathrm{Ca}_{8^{\prime}} \mathrm{T}_{60}+\mathrm{Ca}_{0^{\prime}} \mathrm{T}_{60}+\mathrm{Ca}_{4^{\prime}} \mathrm{T}_{60}+\mathrm{Ca}_{8^{\prime}} \mathrm{T}_{80}+\mathrm{Ca}_{0^{\prime}} \mathrm{T}_{80}$ $+\mathrm{Ca}_{4}, \mathrm{~T}_{80}+\mathrm{Ca}_{8}$ konuları için drene olan su miktarı sırası ile 14.0, 13.6, 13.0, 14.3, 13.7, 13.2, 16.2, $20.0,19.8,22.1,21.8,21.7,32.8,33.2$ ve 32.9 It lizimetre-1 iken bitki su tüketimi değerleri 83.1, 83.5, 84.1, 82.7, 83.4, 83.9, 80.9, 77.1, 77.3, 75.0, 75.3, 75.4, 64.3, 63.9 ve 64.2 It lizimetre $^{-1}$ olarak gerçekleșmiștir.

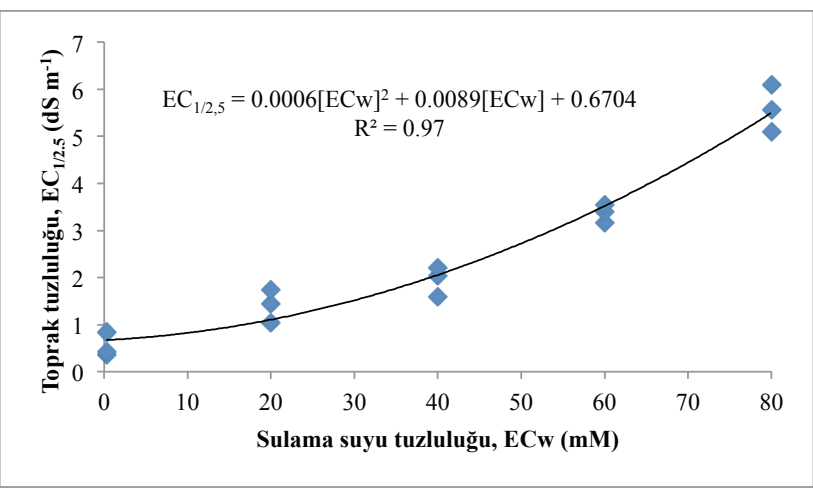

Șekil 2. Sulama suyu tuzluluğu ile toprak tuzluluğu arasındaki ilișki

Figure 2. Relationship between irrigation water salinity and soil salinity

Varyans analizi sonuçlarına göre, havuç veriminin $20 \mathrm{mM}$ sulama suyu tuz konsantrasyonundan etkilenmediği, ancak bu noktadan sonra artan tuz konsantrasyonlarının pazarlanabilir verimi istatistikî olarak önemli miktarda düșürdüğü saptanmıștır (Çizelge 1). Bu araștırmadaki bulgulara paralel olarak, Gibberd vd. (2002) havuç veriminin 20 mM tuz konsantrasyonundan etkilenmediğini, ancak bu noktadan sonra artan tuz konsantrasyonlarının verimde kayıplara sebep olduğunu bildirmiștir.

Diğer taraftan, pazarlanabilir verim üzerine $\mathrm{NaCl}$ x Ca interaksiyonun etkisi istatiksel olarak önemsiz bulunmuștur (Çizelge 1). Bu sonuç, tuzun pazarlanabilir havuç verimi üzerine olan negatif etkilerini azaltmada yapılan ek kalsiyum uygulamalarının etkili olmadığını göstermektedir. Bu bulgulara benzer sonuçlar, marul genotiplerinde (Cramer ve Spurr, 1986) yapılan çalıșmalardan da elde edilmiștir. Buna karșın, biber (Capsicum annuum L.) ve ispanakta (Spinacia olerecea L.) tuzun verim üzerine olumsuz etkilerinin ilave kalsiyum uygulamaları ile azaltılabileceği saptanmıștır (Rubio vd., 2009).

Pazarlanabilir verim sonuçlarına benzer olarak, artan sulama suyu tuz konsantrasyonları havuc köklerindeki su miktarlarını istatistiksel olarak önemli düzeyde etkilemiștir (Çizelge 1). Havuçlarda en yüksek su içeriği 0 ve 20 mM tuz içeren sulama suyu uygulamalarından elde edilirken, en düșük içerikler 40, 60, $80 \mathrm{mM}$ tuz içeren sulama suları ile sulanmıș havuç bitkilerinden elde edilmiștir. Benzer bir çalıșmada, Ispanak (Renault vd., 2001) ve pırasada (Turhan vd., 2014a) su içeriğinin artan tuz konsantrasyonları ile birlikte azaldığı tespit edilmiștir. Öztürk (1997) meyve su içeriğindeki azalmayı, tuzun toksik etkileri nedeni ile bitkilerin daha az su almasına bağlamıștır. İlave kalsiyum uygulamaları yönüyle incelendiğinde, uygulamalar ile havuçların su içeriği arasında önemli istatistikî ilișkiler saptanmamıștır. Bununla birlikte, havuç köklerindeki su içeriği üzerine $\mathrm{NaCl}$ x Ca interaksiyonunun etkisi de önemsiz bulunmuștur.

Çizelge l'den de izlenebileceği gibi, suda çözünür kuru madde miktarları üzerine tuz uygulamalarının etkisi istatistikî olarak önemli bulunmuș ve en yüksek suda çözünebilir kuru madde miktarı 20 mM tuz uygulamasından elde edilmiștir. 20 mM üzerinde artan sulama suyu tuz konsantrasyonlarının söz konusu değerleri önemli miktarda düșürdüğü belirlenmiștir. Çalıșma sonuçlarına paralel olarak bazı araștırmacılar, sulama suyu tuz konsantrasyonlarındaki artıșın havucun suda çözünür kuru madde içeriğini azalttığını raporlamıșlardır (Kahouli vd., 2014). Tuzun ortaya çıkardığı suda çözünür kuru madde miktarındaki kayıpları azaltmak için yapılan 4 ve $8 \mathrm{mM}$ ilave kalsiyum uygulamalarının olumlu etkileri gözlenmiștir. Bu bağlamda, $\mathrm{NaCl} \times \mathrm{Ca}$ interaksiyonun etkisi istatistikî yönden önemli $(p<0.01)$ bulunmuștur. 4 ve $8 \mathrm{mM}$ ilave Ca uygulamaları karșılaștırıldığında, her iki uygulamanın etkileri benzer sonuçlar verirken (20 ve $60 \mathrm{mM} \mathrm{NaCl}$ uygulamaları), 0, $80 \mathrm{mM}$ tuz konsantrasyonlu sulama sularına eklenen $8 \mathrm{mM}$ kalsiyum, suda çözünür kuru madde içeriklerini küçük miktarda da olsa daha fazla artırdığı bulunmuștur (Çizelge 1). 
Çizelge 1. Havuçta, sulama suyu tuzluluğu ve ilave kalsiyum uygulamalarının pazarlanabilir verim, meyve su içeriği, suda çözünür kuru madde, toplam asitlik indirgen șeker, $\beta$-karoten ve vitamin C üzerine etkileri

Table 1. Effects on marketable yield, fruit juice content, water soluble dry matter, total acidity reducing sugar, $\beta$-carotene and vitamin C of irrigation water salinity and additional calcium applications in carrots

\begin{tabular}{|c|c|c|c|c|c|c|c|}
\hline Uygulamalar & $\begin{array}{c}\text { Pazarlanabilir } \\
\text { verim } \\
\left(\mathrm{kg} \mathrm{da}^{-1}\right)\end{array}$ & $\begin{array}{l}\text { Meyve su } \\
\text { içeriği } \\
(\%)\end{array}$ & $\begin{array}{c}\text { Suda çözünür } \\
\text { kuru madde } \\
(\%)\end{array}$ & $\begin{array}{l}\text { Toplam } \\
\text { asitlik (\%) }\end{array}$ & $\begin{array}{l}\text { İndirgen } \\
\text { șeker }(\%)\end{array}$ & $\begin{array}{c}\beta \text {-karoten } \\
\left(\mathrm{mg} 100 \mathrm{~g}^{-1}\right)\end{array}$ & $\begin{array}{l}\text { Vitamin C } \\
\left(\mathrm{mg} 100 \mathrm{~g}^{-1}\right)\end{array}$ \\
\hline $\mathrm{T}_{0} \mathrm{Ca}_{0}$ & 3113.47 & 87.99 & $10.11 \mathrm{de}$ & $0.29 \mathrm{ab}$ & $2,27 \mathrm{c}$ & $5.87 \mathrm{e}$ & $6.31 \mathrm{e}$ \\
\hline $\mathrm{T}_{0} \mathrm{Ca}_{4}$ & 3186.89 & 87.66 & 10.79 bc & $0.26 \mathrm{bc}$ & $2,32 \mathrm{bc}$ & $6.08 d$ & $6.92 \mathrm{c}$ \\
\hline $\mathrm{T}_{0} \mathrm{Ca}_{8}$ & 3216.98 & 87.41 & 11.06 b & $0.25 c$ & $2,41 \mathrm{ab}$ & $6.00 \mathrm{de}$ & $6.30 \mathrm{e}$ \\
\hline $\mathrm{T}_{20} \mathrm{Ca}_{0}$ & 3101.55 & 87.96 & $10.45 \mathrm{~cd}$ & $0.21 \mathrm{~d}$ & $2,36 \mathrm{bc}$ & $6.25 c$ & $6.44 d$ \\
\hline $\mathrm{T}_{20} \mathrm{Ca}_{4}$ & 3181.77 & 87.02 & 11.90 a & $0.16 \mathrm{efg}$ & 2,38 ab & $7.22 \mathrm{~b}$ & 7.70 a \\
\hline $\mathrm{T}_{20} \mathrm{Ca}_{8}$ & 3205.73 & 86.84 & $11.80 \mathrm{a}$ & $0.17 \mathrm{def}$ & 2,47 a & 7.66 a & $7.04 \mathrm{~b}$ \\
\hline $\mathrm{T}_{40} \mathrm{Ca}_{0}$ & 2069.25 & 82.95 & $9.95 \mathrm{e}$ & $0.18 \mathrm{de}$ & 1,41 ef & $3.11 \mathrm{~g}$ & $6.06 \mathrm{~g}$ \\
\hline $\mathrm{T}_{40} \mathrm{Ca}_{4}$ & 2142.50 & 82.23 & $8.66 \mathrm{f}$ & $0.15 \mathrm{efg}$ & 1,49 de & $4.41 \mathrm{f}$ & $6.31 \mathrm{e}$ \\
\hline $\mathrm{T}_{40} \mathrm{Ca}_{8}$ & 2152.73 & 81.76 & $8.48 \mathrm{fg}$ & $0.13 \mathrm{~h}$ & $1,55 \mathrm{~d}$ & $4.37 \mathrm{f}$ & $6.20 \mathrm{f}$ \\
\hline $\mathrm{T}_{60} \mathrm{Ca}_{0}$ & 1978.00 & 80.22 & $8.11 \mathrm{~g}$ & 0.31 a & $1,38 \mathrm{f}$ & $3.06 \mathrm{~g}$ & $5.20 \mathrm{j}$ \\
\hline $\mathrm{T}_{60} \mathrm{Ca}_{4}$ & 1991.50 & 79.68 & $8.19 \mathrm{~g}$ & $0.15 \mathrm{efg}$ & $1,35 \mathrm{f}$ & $3.15 \mathrm{~g}$ & 5.57 । \\
\hline $\mathrm{T}_{60} \mathrm{Ca}_{8}$ & 1976.25 & 80.04 & $8.14 \mathrm{~g}$ & $0.15 \mathrm{efg}$ & $1,38 \mathrm{f}$ & $3.11 \mathrm{~g}$ & $5.65 \mathrm{~h}$ \\
\hline $\mathrm{T}_{80} \mathrm{Ca}_{0}$ & 1172.93 & 78.03 & $7.61 \mathrm{~h}$ & $0.26 \mathrm{bc}$ & $0,75 \mathrm{gh}$ & $2.81 \mathrm{~h}$ & $5.18 j$ \\
\hline $\mathrm{T}_{80} \mathrm{Ca}_{4}$ & 1128.07 & 78.69 & $8.05 \mathrm{gh}$ & $0.14 \mathrm{gh}$ & $0,71 \mathrm{~h}$ & $2.81 \mathrm{~h}$ & $5.61 \mathrm{hl}$ \\
\hline $\mathrm{T}_{80} \mathrm{Ca}_{8}$ & 1139.73 & 78.48 & $8.17 \mathrm{~g}$ & $0.12 \mathrm{~h}$ & $0,83 \mathrm{~g}$ & $2.83 \mathrm{~h}$ & $5.69 \mathrm{~h}$ \\
\hline \multicolumn{8}{|l|}{$\mathrm{NaCl}(\mathrm{mM})$} \\
\hline 0 & 3172.44 а & 87.68 a & $10.65 \mathrm{~b}$ & 0.27 a & $2.33 \mathrm{~b}$ & $5.98 \mathrm{~b}$ & $6.51 \mathrm{~b}$ \\
\hline 20 & 3163.02 a & 87.27 a & 11.39 a & $0.18 \mathrm{c}$ & 2.40 a & 7.04 a & 7.06 a \\
\hline 40 & $2121.49 \mathrm{~b}$ & $82.31 \mathrm{~b}$ & $9.03 \mathrm{C}$ & $0.15 d$ & $1.48 \mathrm{c}$ & $3.96 \mathrm{c}$ & $6.19 c$ \\
\hline 60 & $1981.92 \mathrm{C}$ & $79.98 \mathrm{c}$ & $8.14 d$ & $0.20 \mathrm{~b}$ & $1.37 \mathrm{~d}$ & $3.11 \mathrm{~d}$ & $5.47 d$ \\
\hline 80 & $1146.91 \mathrm{~d}$ & $78.40 \mathrm{~d}$ & $7.95 \mathrm{~d}$ & $0.17 \mathrm{c}$ & $0.76 \mathrm{e}$ & $2.82 \mathrm{e}$ & $5.49 d$ \\
\hline \multicolumn{8}{|l|}{ Ca (mM) } \\
\hline 0 & 2287.04 & 83.43 & $9.25 \mathrm{~b}$ & 0.25 a & $1.63 \mathrm{~b}$ & $4.22 \mathrm{~b}$ & $5.84 \mathrm{C}$ \\
\hline 4 & 2326.15 & 83.06 & 9.52 a & $0.17 \mathrm{~b}$ & $1.65 \mathrm{~b}$ & 4.73 a & 6.42 a \\
\hline 8 & 2338.28 & 82.91 & 9.53 a & $0.17 \mathrm{~b}$ & 1.73 a & 4.79 a & $6.17 \mathrm{~b}$ \\
\hline $\mathrm{NaCl}$ & $* *$ & ** & $* *$ & $* *$ & $* *$ & $* *$ & $* *$ \\
\hline Ca & ns & ns & ** & ** & $* *$ & ** & $* *$ \\
\hline $\mathrm{NaCl} \times \mathrm{Ca}$ & ns & ns & $* *$ & $* *$ & $* *$ & ** & $* *$ \\
\hline
\end{tabular}

*. ** Sırasılyla $p \leq 0.05$ ve 0.01 düzeyinde önemli; ns: önemsiz

Ana etkiler için aynı kolonda yer alan ve aynı harfle belirtilen ortalama değerler \%5 düzeyinde istatistiksel olarak farkllık göstermemektedir.

Havuç köklerinin tadını etkileyen en önemli içerik șeker miktarıdır, en yaygın olarak bulunan șekerler ise fruktoz-glikoz (indirgen șeker) ve sakarozdur (Alasalvar vd., 2001; Lee vd., 2011). Havuç köklerinde yapılan indirgen șeker analiz sonuçlarına göre, șeker içerikleri ile tuz konsantrasyonları arasında negatif, kalsiyum uygulamaları arasında pozitif ilișkiler bulunmuștur (Çizelge 1). Havuç bitkilerinde en yüksek indirgen șeker içerikleri $20 \mathrm{mM}$ uygulamasından elde edilmiștir. Buna karșın, 20 mM üzerinde artıș gösteren sulama suyu 
tuz konsantrasyonları indirgen șeker içeriklerini önemli miktarda düșürmüștür. İndirgen șeker içeriklerindeki bu kayıplar ilave kalsiyum uygulamaları ile bir miktar telafi edilebilmiștir. Nitekim $\mathrm{NaCl} \times$ Ca interaksiyonu önemli bulunmuștur. $8 \mathrm{mM}$ ilave kalsiyum uygulanmıș havuçların indirgen șeker içeriklerinin $4 \mathrm{mM}$ kalsiyum uygulamıș havuçlara göre daha yüksek olduğu tespit edilmiștir $(0,20,40$ ve $80 \mathrm{mM})$. Bu da, tuzun olumsuz etkilerinin azaltılmasında 8 mM ilave kalsiyum uygulamalarının daha etkili olduğunu göstermektedir. Bu araștırmadan elde edilen bulgulara paralel olarak, Turhan vd. (2014b) sarımsak bașlarında tuz stresinin șeker içeriğini düșürdüğünü, Rausch vd. (1996) ile Martinez-Ballesta vd. (2000) ise tuz stresinin olumsuz etkilerinin ilave kalsiyum uygulamaları ile azaltılabileceğini bildirmișlerdir.

Șeker yanında meyve asit içerikleri de tadı belirleyen en önemli karakteristikler içerisindedir (Rodica vd., 2008). Bu çalıșmada, havuç köklerinin toplam asit içerikleri üzerine tuz konsantrasyonları ve kalsiyum uygulamalarının etkisi önemli bulunmuștur (Çizelge 1). En yüksek asit içeriği 0 mM uygulamasında elde edilirken, sulama suyu tuz konsantrasyonlarındaki artıș ile önemli miktarda azalma göstermiștir. Asit içeriklerindeki bu azalmalar 60 mM'dan sonra tekrar artma eğilimine girmiștir. Petersen vd. (1998) domateste tuzluluğun meyve organik asit miktarını arttırdığını, buna karșın Rubio vd. (2009) tuzlu koșullarda yetiștirilen biberde meyve kalitesinin kalsiyum uygulamalarından etkilenmediğini bildirmișlerdir. $\mathrm{NaCl}$ x Ca interaksiyonuna göre görece daha yüksek değerler 4 mM kalsiyum uygulamalarından elde edilmiștir .

Havuçların kendine özgü renkleri karotenoidlerden kaynaklanmaktadır (Rouseff ve Nagy, 1994) ve havuçlarda karotenoidlerin \%80'lik kısmı ß-karoten'den olușmuștur (Jeszka, 1997). Havuç zengin bir $\beta$-karoten kaynağıdır (Sharma vd., 2012). Bu çalıșmada, tuz ve kalsiyum uygulamaları ile havuçlarda $\beta$-karoten içerikleri arasındaki ilișkiler incelenmiștir. Çizelge l'de yer alan istatistikî analiz sonuçlarından da anlașılabileceği gibi, tuz ve ilave kalsiyum uygulamalarının yanı sıra $\mathrm{NaCl}$ x Ca interaksiyonunda $\beta$-karoten içerikleri üzerine etkisi istatistikî olarak önemli bulunmuștur. Havuçlarda $\beta$-karoten içerikleri 20 mM tuz konsantrasyonuna kadar artıș göstermiș, bu değerin üzerinde artan sulama suyu tuz konsantrasyonları $\beta$-karoten içeriklerini önemli miktarda azaltmıștır. Illave kalsiyumun olumlu etkileri 0, 20 ve 40 mM tuz uygulamalarında görülmüștür. Bu çalıșmadan elde edilen bulgulara paralel olarak, daha önce yapılan benzer bir çalıșmada artan $\mathrm{NaCl}$ konsantrasyonlarının nane (Amarantus polygamous L.) bitkisinin $\beta$-karoten içeriklerini azalttığı raporlanmıștır (Ratnakar ve Rai, 2013).

Değișik tuzluluk düzeylerindeki sulama sularının havuç köklerinin Vitamin C içerikleri üzerine önemli istatistikî etkisinin olduğu Çizelge l'den de izlenebilmektedir. 20 mM tuzluluk düzeylerine kadar artıș gösteren Vitamin C içerikleri, $40 \mathrm{mM}$ ve üzerinde artan tuz konsantrasyonları ile önemli miktarda azalma göstermiștir. Benzer bulgular havuç için Tang vd. (2013) ve marul için (Lactuca sativa L. CV. Funly ) Turhan vd. (2014c) tarafından raporlanmıștır. Kim vd. (2008) ile Gautier vd. (2010) ise domates meyvelerindeki Vitamin C içeriklerinin artan tuz konsantrasyonlarının etkisi ile yükseldiğini bildirmișlerdir. Bununla birlikte, tuzluluğun zararlı etkilerinin azaltılmasına yönelik yapılan ilave kalsiyum uygulamalarından olumlu sonuç alınmıș, kalsiyum uygulamalarının etkisi yanında $\mathrm{NaCl}$ x Ca interaksiyonu da istatistikî olarak önemli bulunmuștur. En yüksek Vitamin C içeriği 20 mM tuz ve 4 mM Ca uygulanmasından elde edilmiștir. 4 mM ve 8 mM kalsiyum uygulamaları karșılaștırıldığında, 4 mM kalsiyum uygulamasının havuçların vitamin C içerikleri üzerine olumlu etkilerinin daha yüksek olduğu saptanmıștır. Bu olumlu etkiler özellikle 0, 20 ve 40 mM tuz içeren sulama suları ile sulanan havuçlarda daha belirgindir.

\section{Sonuçlar}

Yapılan çalıșmadan elde edilen sonuçlara göre; artan sulama suyu tuz konsantrasyonları havuç bitkilerinin verimini ve kalitesini olumsuz yönde etkilemiștir. Havuç yetiștiriciliğinde kullanılacak sulama sularının tuzluluk sınırı 20 mM olmalıdır. Bu düzeyin üzerinde artan sulama suyu tuz konsantrasyonları verim ve kalitede önemli miktarda kayıplara sebep olacaktır. Kalsiyumlu gübre uygulamalarının, tuzlu koșullarda yetiștirilen havuç bitkilerinin bazı kalite özelliklerine (suda çözünür kuru madde, indirgen șeker, $\beta$-karoten, vitamin C) olumlu etkilerinin 
olabileceği görülmüștür. Tuzun pazarlanabilir verim üzerine olan negatif etkilerini azaltmada yapılan ilave kalsiyum uygulamalarının etkili olmadığı belirlenmiștir.

\section{Kaynaklar}

Al-Karakı GN (2000). Growth, water use efficiency and sodium and potassium acquisition by tomato cultivars grown under salt stress. J. Plant Nutr. 23(1): 1-8.

Alasalvar C, Grigor JM, Zhang D, Quantick PC, Shahidi F (2001). Comparison of volatiles, phenolics, sugars antioxidant vitamins and sensory quality of different colored carrot varieties. Journal of Agricultural and Food Chemistry, pp: 1410-1416.

Akat H, Özzambak ME (2013). Örtü altı tuzlu koșullarda yetiștirilen Limonium siniatum bitkisinde kalsiyum uygulamalarının stres parametreleri üzerine etkileri. Tekirdağ Ziraat Fakültesi Dergisi, 10(1): 48-58.

Bakhsh K, Ashfaq M, Waqasalam M (2005). Effects of poor quality of ground water on carrot production: a comparative study. Journal of Agriculture and Social Sci. 1:38-40.

Caines AM and Shennan C (1999). Interactive effects of $\mathrm{Ca} 2+$ and $\mathrm{NaCl}$ salinity on the growth of two tomato genotypes differing in Ca2+ use effkiency. Plant Physiol. Biochem., 37: (7/8): 569-576.

Cemeroğlu B (2010). Gıda analizleri. Gıda ve Teknolojisi Derneği Yayınları. No:34 s. 148-149.

Cramer GR, Spurr AR (1986). Responses of lettuce to salinity. I. Effect of $\mathrm{NaCl}$ and $\mathrm{Na}_{2} \mathrm{SO} 4$ on growth. J. Plant Nutri. 9: 115-130.

Ekmekçi E, Apan M, Kara M (2005). Tuzluluğun bitki gelișimine etkisi. OMÜ Zir. Fak. Dergisi. 20(3): 118-125.

Fabre R, Duval M, Jeannequin B (2011). Influence de la salinité sur la qualité gustative et le rendement de tomatesgrefféescultivées hors-sol sous serrechaufféedans le sud de la France. Cah. Agric., 20: 266-273.

Fenn LB, Taylor RM, Binzel MI, Burks CM (1991). Calcium stimulation of ammonium absorption in onion. Agron. J. 83: 840-843.

Gautier H, Lopez-Lauri F, Massot C, Murshed R, Marty I, Sallonon $H$ (2010). Impact of ripening and salinity on tomato fruit ascorbate content and enzymatic activities relate to ascorbate recycling. Funct. Plant Sci. Biotechnol. 4: 66-75.

Gibberd MR, Turner NC, Storey R (2002). Influence of saline irrigation on growth, ion accumulation and partitioning, and leaf gas Exchange of carrot (Daucus carota L.). Annals of Botany, 90: 715-724.

Gormley TR, Maher MJ (1990). Tomato fruit quality an interdisciplinary. Professional Horticulture, 4: 7-12.

Grattan SR and Grieve CM (1999). Salinity mineral nutrient relations in horticultural crops. Scientia Horticulturae 78:127-157.

Hasegawa PM, Bressan RA, Pardo JM (2000). The dawn of plant salt to tolerance genetics. Trends in Plant Sci. 5: 317-319.
Jeszka WJ (1997). Food Colorants.Chemical and functional properties of food components.Technomic Publishing Company, Lancaster, 293 p.

Kahouli B, Borgi Z, Hannachi C (2014). Study of the tolerance of ten accessions of carrot (Daucus carota L.) to salinity. Journal of Stress Physiology and Biochemistry, 3:1827 .

Kara T (2002). Irrigation scheduling to present soil salinization from a shallow water table. Acta Horticulture, 573: 139-151.

Khayyat M, Tafazoli E, Eshghi S, Rahemi M, Rafaee S (2007). Salinity, supplementary calcium and potassium effects on fruit yield and quality of strawberry. AmericanEurasian J. Agric. Environ. Sci. 2(5): 539-544.

Kim HJ, Fonseca JM, Kubota C, Kroggel M, Choi JH (2008). Quality of fresh-cut tomatoes as affected by salt treatment in irrigation water and post-processing ultraviolettreatment. Journal of the Science of Food and Agriculture, 88(11): 1969-1974.

Kwiatowsky J (1998). Salinity Classification, Mapping and Management in Alberta. http://www.agric.gov.ab.ca/ sustain/soil/salinity/

Lahaye PA and Epstein E (1971). Calcium and salt toleration by bean plants, Physiol. Plant. 25: 213-218.

Lee EJ, Yoo KS, Patil BS (2011). Total carotenoid, anthocyanin, and sugar contents insliced or whole purple (cv. Betaweet) and orange carrots during 4 weeks cold storage. Horticulture, environment and Biotechnology, 52(4): 402-407.

Martinez-Ballesta M, Martinez V, Carvajal M (2000). Regulation of water channel activity in whole roots of melon plants grown under saline conditions. Aust. J. Plant, 27: 685-91.

Munns R (2002). Comparative physiology of salt and water stress. Plant, Cell and Environment, 25: 239-250.

Navarro JM, Botella MA, Cerdá A, Martinez V (2000). Effect of salinity $x$ calcium interaction on cation balance in melon plants grown under two regimes of orthophosphate. J. Plant Nutr. 23: 991-1006.

Noshadi M, Fahandej S, Sepaskhah AR (2013). Effects of salinity and irrigation water management on soil and tomato in drip irrigation. International Journal of Plant Production, 7(2): $1735-8043$.

Öztürk A (1997). Sulama suyu tuzluluğu ve taban suyu derinliğinin havuç bitkisinin bazı özelliklerine etkisi. Tarım Bilimleri Dergisi. 3(1): 54-58.

Petersen KK, Willumsen J, Kaack K (1998). Composition and taste of tomatoes as affected by increased salinity and different sources. Journal of Horticultural Science and Biotechnology, 73: 205-215.

Pierson D (1970). The Chemical Analysis of Food. Auxil, London.

Ratnakar A, Rai A (2013). Effect of NACL salinity on $\beta$-carotene, thiamine, riboflavin and ascorbic acid contents in the leaves of Amaranthus polygamous L. Var. 'PusaKırti'. Oct. Jour. Env. Res. 1(3): 211-216. 
Rausch T, Kirsch M, Lfiw R, Lehr A, Viereck R, Zhigang $A(1996)$. Salt stress responses of higher plants: the role of proton pumps and $\mathrm{Na}+/ \mathrm{H}+$ antiporters. In: Lichtenthaler HK, ed. Vegetation stress. Journal of Plant Physiology, 148: 425-33.

Reid RJ and Smith A (2000). The limits of sodium/calcium interactions in plant growth. Aust. J. Plant Physiol. 27: 709715.

Renault S, Croser C,Franklin JA, Zwiazek JJ (2001). Effects of $\mathrm{NaCl}$ and $\mathrm{Na2SO} 4$ on red-osier dogwood (Cornus stolonifera Michx) seedlings. Plant Soil, 233: 261-268.

Renault R. and M. Affifi (2009). Improving NaCl resistance of red-osier dogwood: role of $\mathrm{CaCl} 2$ and CaSO4. Plant Soil, 315:123-133.

Rhoades JD, Kandiah A. and Mashali AM (1992). The Use of sahne waters for crop production. FAO kr. and Drain. Paper, Rome, 48:1-133.

Rodica S, Apahıdean SA, Apahıdean M, Manıtıu L, Paulette $L$ (2008). Yield, physical and chemical characteristics of greenhouse tomato. 1092 Afr. J. Agric. Res. Grown on Soil and Organic Substratum. 43rd Croatian and 3rd Int. Symposium on Agric. Opatija. Croatia. pp. 439-443.

Rouseff RL, Nagy S (1994). Health and nutritional benefits of citrus fruits components. Food Technol. 11: 125-132.

Rubio JS, Garcia-Sanchez F, Rubio V, Martinez (2009). Yield, blossom-end rot incidence, and fruit quality in pepper plants under moderate salinity are affected by $\mathrm{K}+$ and $\mathrm{Ca} 2+$ fertilization. Scientia Horticulturae, 119: 79-87.

Sharma DT, Karki S, Thakur NS, Attri S (2012). Chemical composition, functional properties and processing of carrot-a review. J. Food Sci. Technol. 49(1):22-32.
Tang $\mathrm{H}$, Hu H, Ye M, Jin H, Lin X (2013). Effects of soil salinity on the quality of carrot. Subtropical Plant Science, 42(2): 113-116.

Tigchelaar EC (1986). Tomato breeding. In: Basset M.J. (ed.) Breeding Vegetables Crops, Westport, USA, pp. 135170.

Turhan A, Kușçu H, Özmen N(2014a). Farklı tuzluluk düzeylerindeki sulama sularının pırasada verim ve bazı kalite parametrelerine etkisi. 10. Sebze Tarımı Sempozyumu. Bildiriler (I): 131-136. 2-4 Eylül 2014,Tekirdağ.

Turhan A, Kuscu H, Ozmen N, Demir AO (2014b). Farklı tuzluluk düzeylerinin sarımsakta (Allium sativum L.) verim ve bazı kalite özelliklerine etkisi. Journal of Agricultural Sciences, 20: 280-287.

Turhan A, Kuscu H, Ozmen N, Serbeci MS, Demir AO (2014c). Effect of different concentrations of diluted seawater on yield and quality of lettuce. Chilean Journal of Agricultural Research, 74(1): 111-116.

Ünlükara A, Cemek B, Kesmez D, Öztürk A (2011). Carrot (Daucus carota L.): yield and quality under salinity conditions. Anadolu Tarım Bilim. Derg., 26(1): 51-56.

Viegas RA, Silveira JAG, Junior ARL (2001). Effects of $\mathrm{NaCl}$-salinity on growth and inorganic solute accumulation in young cashew plants. Braz. J. Environ. Agric. Eng. 5: 216-222. 66- 71 .

Zhu JK (2001).Plant salt tolerance. Trends Plant Sci., 6: 